UDC. $543.423 .86: 669.15-194$

\title{
螢光 X線によろ鉄鋼分析法（4）
}

\section{(吸收励起効果の補正係数の変動について)}

Fluorescent X-Ray Analysis of Steels (4)

(On Variation of Correction Factors of Absorption and Enhancement Effects)

$\begin{array}{llll}\text { 会員足 立 敏 } & \text { 夫 } \\ \text { 同 伊 藤六 } & \text { 右 }\end{array}$

\section{1. 緒 镸}

合金鋼の蓝光X線分析においては定量元素の 含量が同じでも共存元素の変動により蛍光 $\mathrm{X}$ 線 強度が異なる。てれは主として吸収励起効果と 波長の重なりによるもので，それぞれについて 補正法が検討され正確度の良い補正結果が発表 されている。波長の重なりの程度は与えられた 装置および分析条件での分解能に㳖存するの で, 測定条件での波長の重なり量を決める必要 があるが，吸収励起効果が装置わよび分析条件 によりどのように変るかてついては従来の報告 は一定していない。吸収励起効果が分析条件に よって変化しなければ報告に現われた補正式を そのまま用いて分析できるてとになり，合金鋼 の蛍光X線分析は非常に容葛になる。

本報告では吸収励起勃果が $\mathrm{X}$ 線管球の電圧 ・ 電流，ターゲットおよび装置によってどのよう 亿変るが検討し，異った分析条件での測定值 に先の報告の補正式ををのまま適用し良好な結 果を得たととを報告する。

\section{2. 吸収励起奻果の補正式の変動}

装置およぴ分析条件による䖢光 X楾強度の変 化わよび一定条件での再現性についてはすでに 報告され(1)2)，乙の標準化のために主として次の ような方法がとられている。

(1) 純金属の蛍光X線強度との比 ${ }^{3) 4}$ をとる。
(2) 同じような鋼種の標準試料の営光 X線強 度との比をとる ${ }^{115)}$ 。

(3) 標準試料を用いて検量線を作裂しその読 取值を用いる677。

このような標準化後でも吸収励起効果のため 蛍光 $\mathrm{X}$ 線強度は含量と比例せずその補正が必要 であり，てのため補正式の諸数值が分析条件に よって変化するかどうかが問題になる。いま標 準化された $i$ 元素の蛍光 $X$ 線強度を $I i ， i$ 元素 の含量を Wi とするとき，補正式は

$$
\mathrm{Wi}_{\mathrm{i}}=\mathrm{f} \quad(\mathrm{Ii})
$$

として定められるので I i が変化するかどうか ということにもなる。

これにたいし Koh および Cavghertyは (1) で標準化された蛍光X線強度が管球電圧によっ

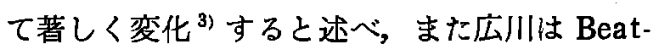
tie および Brissey の補正式の数值を文献に現 われた測定值より求めて，補正式が管球電圧・

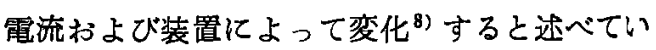
る。杉本は(2)で標準化された強度比が分析条件 によって若干変動する結果を得ているが ${ }^{11}$, 装 置わよび分析条件が異っても補正式がそのまま

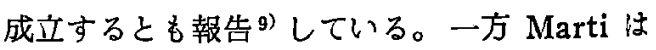
Neff の実験結果より補正式がー次X線にも装 置にも影響されないと年述べており，一柳およ び沢田は銅一ニッケル合金について彼らの補正 
式の数值が管球電圧・霓流で変化しないと報

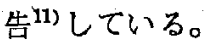

著者らは先に(3)の方法で標準化した蛍光X線 強度を用いて（2）の補正式を呈出した6)。乙 のとき検量線は定量元素と鉄との 2 元系試料を 用けて作製した。以下ての検量線を標準检量線 とよぶ。

$$
\frac{W i}{i(x)}=1+\sum_{j} \operatorname{aij} W_{j}
$$

$W i, W j ; i$ または $j$ 元素の含量\%。

$\mathrm{i}(\mathrm{x}) \quad ; \mathrm{i}$ 元素の紗光 $\mathrm{X}$ 線強度を $\mathrm{i}$ 元素 の標準検量線での読取值で表し たもの。

aij ; i 元素定量にさいし共存元素 $\mathrm{j}$ 亿よって定まろ常数。

補正式の変動を見るためには（2）式の aij を直接調べなくても，i（x）または $\mathrm{Wi} / \mathrm{i}$

（x）が分析条件に上りどのように変化するか 㔬検討すればよい。

\section{3. 管球電圧・電流による補正式の変動}

3.1 装 置

島津製FX402型営光 X 線分析装置，W管球， $\mathrm{LiF}$ 平面分光結晶, 1 次コリメーター $12^{\prime}$ ，
2 次コリメーター $48^{\prime}$, Amperex GM 計数管, 試料マスク $15 \mathrm{~mm} \times 25 \mathrm{~mm}$ 使用した。 $\mathrm{X}$ 線 通路の察围気は空気で雷光 X線强度が强いとき は Al 箈を計数管直前に㨉入した。

\section{2 实酸方法および成料}

検討する因子としては管球電圧，管球電流， 元素および試料を選び，それぞれの組合せにつ いて $\mathrm{Wi} / \mathrm{i}(\mathrm{x})$ を繰返し測定をして因子の水 準による差を検討した。

管球電圧・電流については $50 \mathrm{KV} 20 \mathrm{~mA} ， 40$ $\mathrm{KV} 20 \mathrm{~mA}, 30 \mathrm{KV} 20 \mathrm{~mA}, 40 \mathrm{KV} 30 \mathrm{~mA}, 40 \mathrm{~K}$ V10mA の 5 つの組合せで行った。また元素と しては波長の重なりの影響を避けるため，合金 鋼試料で波長の重なりがはとんど認められない $\mathrm{Ni}, \mathrm{Cr}$ および Mo を選んだ。

$\mathrm{Wi} / \mathrm{i}(\mathrm{x})$ を検討するさい $\mathrm{i}(\mathrm{x})$ は $\mathrm{i}$ 元素の 標準検量線での読取值なので，测定試料が $\mathrm{Fe}$ 一 $\mathrm{i}$ 系 2 元合金之近い組成ならば分析条件の変 化にたいして検量線の変動と同じ変動をするこ とが考えられ，分析条件の影響を検出しがたく なる。とのため測定試料としては Wi / i (x) が 1 より大く偏るように第 1 表のでとく共存元素 が大量に入った試料を電気焒で溶解して作製し 使用した。

\begin{tabular}{|c|c|c|c|c|c|c|c|c|c|c|}
\hline 試 料 & 測 定 元 素 & $\mathrm{C}_{(8)}$ & $S i_{(\%)}$ & $\mathrm{Mn}_{(\mathscr{B})}$ & $P_{(\%)}$ & $S_{(\%)}$ & $\mathrm{Cu}_{(\%)}$ & $\mathrm{Ni}(\%)$ & $\mathrm{Cr}(\%)$ & Mo (q) \\
\hline $\mathrm{X} 2001$ & $\mathrm{Ni} \cdot \mathrm{Cr}$ & 1.08 & 1.16 & 10.30 & 0.033 & 0.024 & 1.96 & 9.84 & 9.85 & 1.80 \\
\hline $\mathrm{X} 2002$ & $\mathrm{Cr} \cdot \mathrm{Mo}$ & 2.01 & 1.40 & 20.72 & 0.075 & 0.024 & 1.96 & 19.56 & 9.88 & 3.68 \\
\hline $\mathrm{X} 2003$ & $\mathrm{Ni} \cdot \mathrm{Mo}$ & 1.05 & 1.96 & 19.52 & 0.020 & 0.019 & 2.09 & 10.06 & 19.67 & 3.65 \\
\hline $\mathrm{X} 2004^{*}$ & & 2.26 & 2.13 & 10.71 & 0.034 & 0.022 & 2.11 & 19.11 & 19.93 & 1.97 \\
\hline $\mathrm{X} 2005$ & Mo & 1.25 & 1.22 & 11.37 & 0.041 & 0.016 & 4.13 & 21.36 & 21.50 & 3.77 \\
\hline $\mathrm{X} 2006$ & $\mathrm{Ni}$ & 2.10 & 1.46 & 19.42 & 0.034 & 0.022 & 3.89 & 10.09 & 19.35 & 1.99 \\
\hline $\mathrm{X} 2007$ & $\mathrm{Ni} \cdot \mathrm{Cr} \cdot \mathrm{Mo}$ & 2. 19 & 1.61 & 10.21 & 0.042 & 0.020 & 3.93 & 9.89 & 10.22 & 3.69 \\
\hline X2008 & $\mathrm{Cr}$ & 1.23 & 2.03 & 18.77 & 0.015 & 0.017 & 3.73 & 19.15 & 9.95 & 1.89 \\
\hline
\end{tabular}

第 1 表 管球電圧電流の影響検討用試料

*4の検討に使用したので附記した。

i（X）㕝測定するのに用いる検量線は一般 に曲線になるが，曲線作製の誤差を避けるため 亿検討用試料とできるだけ同合量の 2 元系試料 を 2 コ選んで標準試料とし，との 2 点間の直線
を求めて検量線とした。との標準試料を第 2 表 に示す。

試料の調製は第 1 報 $^{12)}$ のごとく60番グライン ダー仕上げとし，試料仕上面による誤差を少く 
第 2 表 標準検量線用試料

\begin{tabular}{|c|c|c|c|c|c|}
\hline \multicolumn{2}{|c|}{$\mathrm{Ni}$ 標準倹量線 } & \multicolumn{2}{|c|}{ Cr 標淮検量線 } & \multicolumn{2}{|c|}{ Mo 標準娭量線 } \\
\hline 票準試料 & \begin{tabular}{|l} 
標準傎 \\
$($ (\%)
\end{tabular} & 標 & \begin{tabular}{|l} 
栖集值 \\
(86)
\end{tabular} & 標準試料 & $\begin{array}{l}\text { 標準作 } \\
\text { (\$6) }\end{array}$ \\
\hline & 13. 11 & $21-1$ & 9.30 & Mo -1 & 5. 10 \\
\hline $\mathbf{N i}-2$ & 9.90 & $\mathrm{Cr}-2$ & 7.63 & Mo -2 & 2.85 \\
\hline
\end{tabular}

するため各測定間に 3 回仕上げ直しを行った。 試料の取付位置は仕上方向が X線通路と平行と し，各仕上面ごとに 3 回おき直して測定した。 1 回の測定はX線強度に応して 200 600sec の 定時計数を行った。ただし同じ分析条件・同じ 元素の測定の計数時間は一定にした。

検出器が $\mathrm{GM}$ 計数管なので測定器の数え落と、 しの誤差を除くため杉本の方法 ${ }^{5}$ 亿より不感時 間を求めその補正をした。不感時間測定の誤差 はは㳊同じ蛍光X線強度の標準試料 2 コを用い て検量線を作製しているので，ての面でも補正 が行われる。

\section{3 実験結果わよび考察}

3.2 にしたがって測定を行い各仕上げ直しで とに平均值を求めて $\mathrm{Wi} / \mathrm{i}(\mathrm{x})$ を計算した。 元素および試料別の $W i / i(x)$ の平均值は第 3 表のごとくで共存元素量が異なりかつ測定波長 が異なるので有意差が現われるのは当然であ る。各測定值より第 3 表の值を差引き元素わよ び試料別の平均よりの偏りを求めた。ての偏り が管球電圧・電流, 元素わよび試料の各水準に よって差があるかどうかを分散分析した結果， 元素，管球電圧・電流および元素 X管球電圧・ 電流の交互作用に強度の有意差が認められた。 元素わよび管球電圧 ・電流別の Wi / i ( $\mathrm{x}$ )の平 均値は第 4 表および第 5 表のでとくである。

第 3 表 元素および試料别の $\mathrm{Wi} / \mathrm{i}(\mathrm{X})$

\begin{tabular}{|c|c|c|c|}
\hline 元素 & $\mathrm{Ni}$ & $\mathrm{Cr}$ & $\mathrm{Mo}$ \\
\hline $\mathrm{X} 2001$ & 0.9221 & 1.1474 & - \\
$\mathrm{X} 2002$ & - & 1.2230 & 0.9612 \\
$\mathrm{X} 2003$ & 0.8799 & - & 0.9235 \\
$\mathrm{X} 2005$ & - & - & 0.9484 \\
$\mathrm{X} 2006$ & 0.8994 & - & - \\
$\mathrm{X} 2007$ & 0.8907 & 1.1587 & 0.9714 \\
$\mathrm{X} 2008$ & - & 1.1992 & - \\
\hline
\end{tabular}

第 4 表 管球霞圧による Wi $/ \mathrm{i}(\mathrm{X})$ の変動 ${ }^{*}$

\begin{tabular}{|c|c|c|c|}
\hline 霹压／元素 & $\mathrm{Ni}$ & $\mathrm{Cr}$ & Mo \\
\hline $30 \mathrm{~K} \mathrm{~V}$ & 0.8970 & 1.1755 & 0.9704 \\
\hline $40 \mathrm{~K} \mathrm{~V}$ & 0.8973 & 1.1838 & 0.9455 \\
\hline $50 \mathrm{~K} \mathrm{~V}$ & 0.8973 & 1.1841 & 0.9454 \\
\hline
\end{tabular}

*電流 $20 \mathrm{~mA}$

第 5 表 管球電流による Wi/i (X) の変動*

\begin{tabular}{|c|c|c|c|}
\hline 電流/ 元素 & $\mathrm{Ni}$ & $\mathrm{Cr}$ & $\mathrm{Mo}$ \\
\hline $10 \mathrm{~m} \mathrm{~A}$ & 0.8998 & 1.1843 & 0.9471 \\
$20 \mathrm{~m} \mathrm{~A}$ & 0.8973 & 1.1838 & 0.9455 \\
$30 \mathrm{~m} \mathrm{~A}$ & 0.8986 & 1.1829 & 0.9471 \\
\hline
\end{tabular}

* 電圧 $40 \mathrm{~K} \mathrm{~V}$

この結果から管球電圧，電流により $\mathrm{Wi} / \mathrm{i}(\mathrm{x})$ に有意差があり，との影響は元素でとに異なる てとがわかったが，合金鋼の分析で許容誤差を 合量の $1 \%$ 以下とすれば $30 \mathrm{KV}$ におけるMoの 值を除くと実用的には影響がないともいえる。 一般浖光 $\mathrm{X}$ 線分析で管球電生は測定元素の励 起電圧の 2 倍以上が望ましいとされている ${ }^{13)} の$ で，励起電圧 $20 \mathrm{KV} の$ Moにたいして管球電圧 $30 \mathrm{KV}$ での測定は等際には行われないと考えら れる。

元素および試料別の平均值よりの偏りが試料 間で有意差を認めなかったととより，管球電圧 -電流によって鉄系 2 元合金に近い組成の試料 でも第 1 表にあげたような試料と同程度の影響 を受けると考えるよりる，第 3 表のようにWi/ $\mathrm{i}(\mathrm{x})$ が似かよった試料䓛選んだために差が検出 されなかったと考光るべきであろう。てれにつ いては 4 で述べる。

4. 管球ターゲットおよび装置による補正式 の変動

\section{1 “装置}

島津繁 FX 402 型蛍光 X線分析装置，W管球 をとりつけた ARL製（Applied Reseach Labratory，米国) VPXQおよび Pt管球をとり つけた島津・ARL 製X線カントメーター（VX Q）を用いた。 FX402は 3.1 と同様であり，V PXQ および VXQはともにモ二ター補渞方式 で，試料マスクは $28 \mathrm{~mm} \phi$, 分光光学系は集中 法を採用し，X線通路は真空である。虫た多数 
第 6 表 VXQおよびV P X Qの明紐

\begin{tabular}{|c|c|c|c|c|c|c|c|c|}
\hline 装 置 & \multicolumn{4}{|c|}{$\mathrm{V} \mathbf{X} \mathbf{Q}$} & \multicolumn{4}{|c|}{ V P X Q } \\
\hline 多ーゲッ & \multicolumn{4}{|c|}{$\mathrm{Pt}$} & \multicolumn{4}{|c|}{ W } \\
\hline 則定元素 & 敛 出 器 & 結 晶 & $\begin{array}{l}1 \text { 次スリ } \\
ッ ト\end{array}$ & 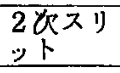 & 椧 出 器 & 結 晶 & $\begin{array}{l}1 \text { 次スリ } \\
\text { ット }\end{array}$ & $\begin{array}{l}2 \text { 次スリ } \\
y ト\end{array}$ \\
\hline Ni Ka & Ar マルチトロン & $4^{\prime \prime} \mathrm{LiF}$ & $0.020^{\prime \prime}$ & $0.030^{\prime \prime}$ & Ar マルチトロン & $11^{\prime \prime} \mathrm{iLF}$ & $0.030^{\prime \prime}$ & $0.060^{\prime \prime}$ \\
\hline Cr Ka: & Ar マルチトロン & $4^{\prime \prime} \mathrm{LiF}$ & $0.020^{\prime \prime}$ & $0.04 C^{\prime \prime}$ & Ar マルチトロン & $4^{\prime \prime} \mathrm{LiF}$ & $0.02 \mathrm{C}^{\prime \prime}$ & $0.040^{\prime \prime}$ \\
\hline MoK $\alpha$ & Kr マルチトロン & $11^{\prime \prime} \mathrm{LiF}$ & $0.020^{\prime \prime}$ & $0.030^{\prime \prime}$ & $\mathrm{Kr}$ マルチトロン & $11^{\prime \prime} \mathrm{LiF}$ & $0.010^{\prime \prime}$ & $0.020^{\prime \prime}$ \\
\hline
\end{tabular}

回路同時測定方式で各元素でとの明練は第 6 表 に示した。

第 7 表 測 定 条 件

\begin{tabular}{|c|c|c|c|}
\hline 装＼cjkstart置 & 測定元素 & $\begin{array}{l}\text { ターケ } \\
\text { ット }\end{array}$ & 管球電圧電流 \\
\hline F X 402 & $\mathrm{Cr}$ & W & $\begin{array}{l}40 \mathrm{~K} \mathrm{~V} 10 \mathrm{~mA} \text { お } \\
30 \mathrm{~K} \text { V } 10 \mathrm{~m} \mathrm{~A}\end{array}$ \\
\hline $\mathrm{VX} \mathbf{Q}$ & $\mathrm{Ni} \cdot \mathrm{Cr} \cdot \mathrm{Mo}$ & $\mathbf{P t}$ & $40 \mathrm{~K} \mathrm{~V} 30 \mathrm{~mA}$ \\
\hline V P X Q & $\mathrm{Ni} \cdot \mathrm{Cr} \cdot \mathrm{Mo}$ & W & $40 \mathrm{~K} \mathrm{~V} 30 \mathrm{~m} \mathrm{~A}$ \\
\hline
\end{tabular}

\section{2 実戨方法わよび武料}

管球ターゲットおよび装置による補正式の変 動を調べるため, 同じ陚料を第 7 表の各条件で 湘定し比較した。

この実験では補正式が実用的にどのように変 わるかをみるためめ，実際の合金鋼の製品おる び炉中試料中よりできるだけ共存元素の含量が 変化している試料を選んで第 1 表の試料ととも

第 8 表 ターゲットおよび装置の影響検討用試料

\begin{tabular}{|c|c|c|c|c|c|c|c|c|c|c|c|c|}
\hline $\begin{array}{l}\text { 些較した } \\
\text { 致置 }\end{array}$ & 测定 & 数料 & $\mathrm{C}(\%)$ & Si (\$) & $\operatorname{Mn}(\$)$ & $\mathrm{Cu}(\%)$ & $\mathrm{Ni}(56)$ & $\mathrm{Cr}(\%)$ & $\mathrm{Mo}(\%)$ & $\mathrm{W}($ (क) & $V(\%)$ & $\mathrm{Co}(\%)$ \\
\hline V P X Q & $\mathrm{Ni}$ & 25 & $0.0 \sim 2.3$ & $0.2 \sim 2.1$ & $\mid \begin{array}{l}0.2 \sim 20.7 \\
-\simeq 2\end{array}$ & $0.1 \sim 4.1$ & $\begin{array}{r}1.7 \sim 19.6 \\
\end{array}$ & $\begin{array}{l}5.0 \sim 21.5 \\
\end{array}$ & $0.0 \sim 3.7$ & & & \\
\hline 対 & $\mathrm{Cr}$ & 58 & 00 & 5.1 & $\begin{array}{r}0.2 \sim \\
21.4\end{array}$ & 1.1 & $\begin{array}{r}0.1 \sim \\
21.4 \\
\end{array}$ & $\begin{array}{r}4.0 \sim 21.5 \\
\end{array}$ & $0 \sim 9.2$ & $\begin{array}{r}0 \sim \\
18.6\end{array}$ & 0.0 & $\begin{array}{r}0.0 \sim 11.1 \\
\end{array}$ \\
\hline $\mathrm{VXQ}$ & Mo & 24 & $0.0 \sim 2.3$ & 2.1 & $\begin{array}{r}0.2 \sim 20.7 \\
\end{array}$ & 0. & $0.1 \sim 21.4$ & $4.0 \sim 21.5$ & 0 & & $0.0 \sim 4.1$ & $\begin{array}{r}0.0 \sim 11 \\
\end{array}$ \\
\hline $\begin{array}{l}V P X Q \\
\text { 䇃 } \\
F \text { X } 402\end{array}$ & $\mathrm{Cr}$ & 45 & 00 & $0.0 \sim 5.1$ & $0.2 \sim$ & 0 & $\mid 0.1 \sim 19.6$ & $\mid \begin{array}{l}3.8 \sim 12.2 \\
\end{array}$ & 0 & & & \\
\hline
\end{tabular}

に用いた。これを第 8 表に示す。なお測定の都 合により FX402 では Crのみを比較し，また測 定試料も VXQ に用いた試料中の 1 部范用い た。

各試料について蛍光 X線強度を湘定し, 標隼 検量線での読取值 $\mathrm{i}(\mathrm{x})$ を求め, 各測定条件で の $\mathrm{i}(\mathbf{x})$ を比較することにより補正式の変動状 沅をみた。

\section{3 実験結果および考察}

4. 2 亿したがって各条件で $\mathrm{i}(\mathrm{x})$ を測定し， VPXQ での $\mathrm{i}(\mathrm{x})$ と他の条件での $\mathrm{i}(\mathrm{x})$ を比較 した。その 1 部を第 1 ～ 5 図に示す。

第 1 沧より合金鋼試料では比較的良く一致す るが第 1 表に示した特殊試料では差が大きい。 てれは第 1 表の試料では共存元素全部の含量が 多く $\mathrm{Wi} / \mathrm{i}(\mathrm{x})$ の 1 よりの偏りか特に大きいた め，測定条件の変化の影響を大きく受けたもの

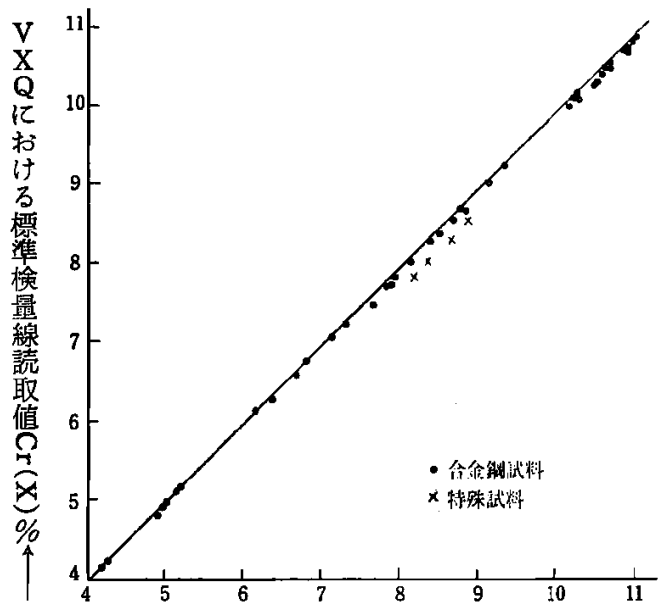

$\longrightarrow V P X Q に お け る$ 標準検量線読取値 $\mathrm{Cr}(\mathrm{X}) \%$

第 1 図 $\mathrm{VXQ} \cdot \mathrm{Pt}$ ター゙ットと $\mathrm{VPXQ} \cdot \mathrm{W}$ ター ゲットとでの Cr(X)の比較 


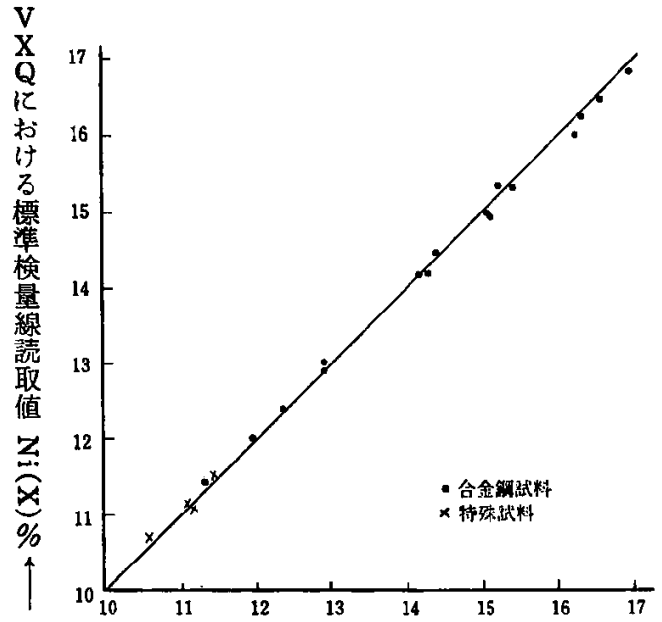

$\longrightarrow$ VPXQ亿求ける標準検量線読取值Ni（X)\%

第 2 図 VXQ・Pt ターゲットと VPXQ・Wター ゲットとでの Ni(X) の比較

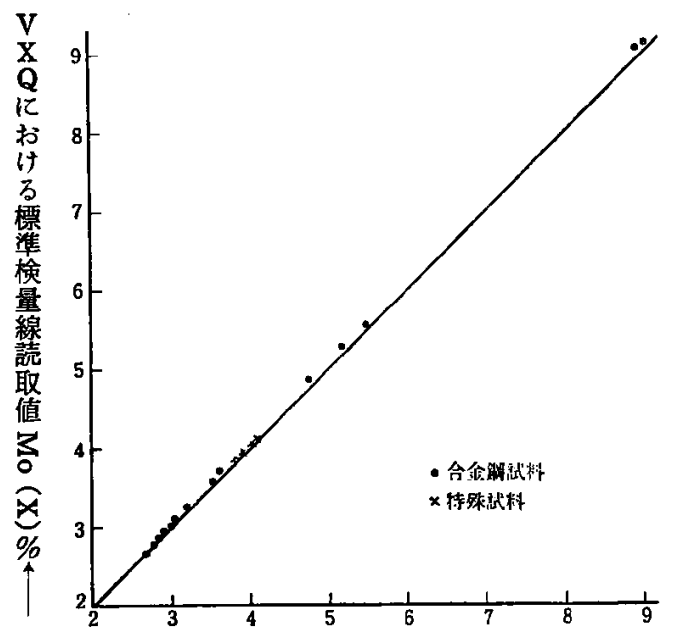

$\longrightarrow V P X Q$ 亿おける標準検量線䚋取值 Mo(X)\%

第3図 VPX・Ptターゲットを VPXQ・Wター ゲットとでの Mo(X) の比较

と考えられる。合金銅の製造過程ではてのよう な組成は現われないので実用的にはこれらの試 料を無視するととができよう。

第 1 表の特殊試料を除いて VPXQ による $\mathrm{i}(\mathrm{x})$ と他の条件での $\mathrm{i}(\mathrm{x})$ との差の平均值およ びバラッキを求めると第 9 表のどとくなった。

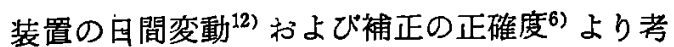
えて測定条件が異っても同じ補正式を採用でき ると考えら和る。しかし同一測定条件で長期間 分析を行うときにはその条件での補正式を求め るととが望ましいのは勿論である。

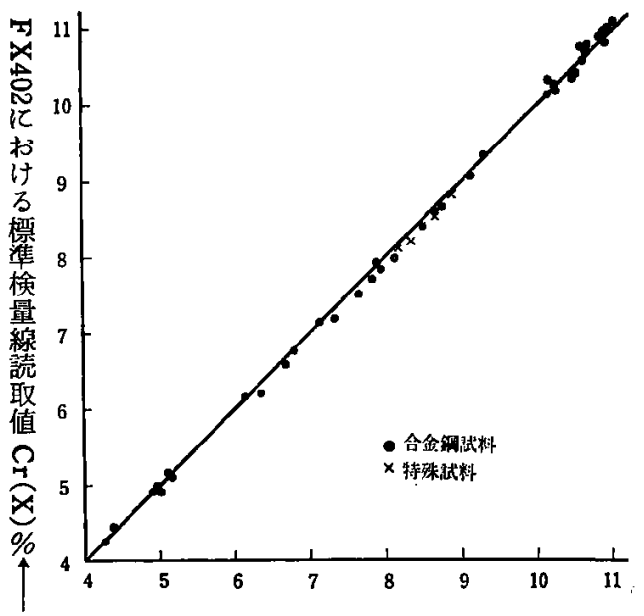

—VPXQにおける標準検量線読取值 $\mathrm{Cr}(\mathrm{X}) \%$ 第 4 图 FX402 $40 \mathrm{RV} / 10 \mathrm{~mA}$ と VPXQ $\cdot 40 \mathrm{KV}$ $130 \mathrm{~mA}$ とでの $\mathrm{Cr}(\mathrm{X})$ の此勈

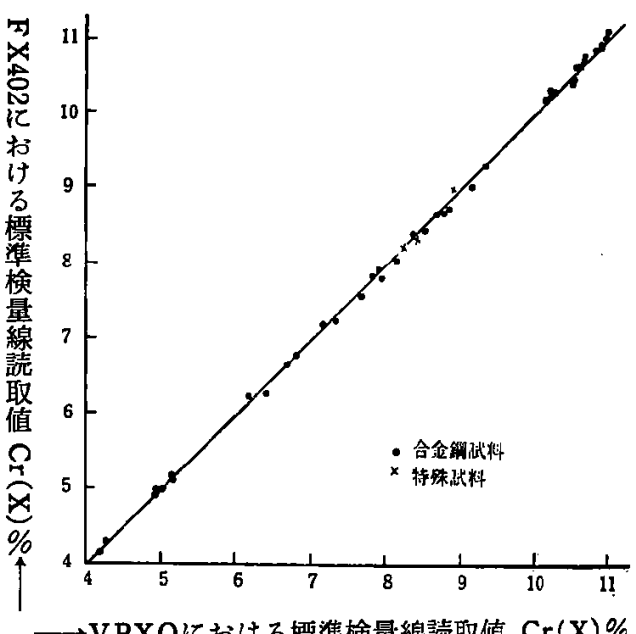

一VPXQにわける標準検量線読取值 $\mathrm{Cr}(\mathrm{X}) \%$

第 5 図 $\mathrm{FX} 402 \cdot 30 \mathrm{KV} / 10 \mathrm{~mA}$ とVPXQ $\cdot 40 \mathrm{KV} /$ $30 \mathrm{~mA}$ とでの $\mathrm{Cr}(\mathrm{X})$ の比較

5. 鉄系 2 元合金試料がないときの補正式の 適用法

5.1 補正式の適用法

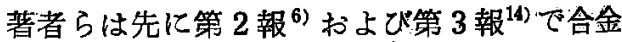

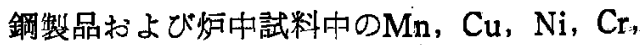
Moの定量にたいし標準検量線を使用する補正 式を提出し，良い正確度で分析が行われるとと を報告した。また 3 および4においててれら補 正式の諸数值を他の分析条件の測定值適用し ても大きな誤差が生じないてとを示した。 


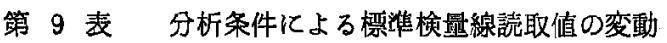

\begin{tabular}{|c|c|c|c|c|c|c|}
\hline \multirow{3}{*}{$\begin{array}{l}\text { 分 } \\
\text { 析 } \\
\text { 条 } \\
\text { 件 }\end{array}$} & 㯰 & \multicolumn{2}{|c|}{ F X 402} & \multicolumn{3}{|c|}{$\mathrm{VX} \mathbf{Q}$} \\
\hline & ターゲット & \multicolumn{2}{|c|}{$\mathrm{W}$} & \multicolumn{3}{|c|}{$\mathrm{Pt}$} \\
\hline & 電圧 / 電流 & $40 \mathrm{~K} \mathrm{~V} / 10 \mathrm{~m} \mathrm{~A}$ & $\mid 3) \mathrm{K} \mathrm{V} / 10 \mathrm{~mA}$ & \multicolumn{3}{|c|}{$40 \mathrm{~K} \mathrm{~V} / 30 \mathrm{~m} \mathrm{~A}$} \\
\hline 测 & 定 元 素 & $\mathrm{Cr}$ & $\mathrm{Cr}$ & $\mathrm{Ni}$ & $\mathrm{C}_{\mathrm{r}}$ & Mo \\
\hline 試 & 料 数 $\mathrm{n}$ & 45 & 45 & 17 & 50 & 16 \\
\hline 差 0 & D平均 $\bar{d}$ & -0.009 & +0.010 & -0.017 & -0.063 & +0.022 \\
\hline 差の & 標準偏差 od & 0.066 & 0.062 & 0.065 & 0.051 & 0.035 \\
\hline
\end{tabular}

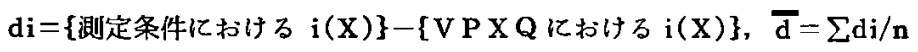
$\sigma d=\sqrt{\Sigma d i-d)^{2} /(n-1)}$

しかし著者らの補正式を適用するには第 2〜 3 報で述べたでとく鉄系 2 元合金の標準試料よ り作製した標準検量線と波長の重なりがあると きにはその重なり量を示す Di が必要となり， ての Di もまた鉄系 2 元合金試料より求めなけ ればならない。

しかし補正式の諸数值がそのまま使用できる となると鉄系 2 元合金試料がなくても，必要と する定量範囲にて組成の判明した試料があれば それを用いて逆に標準検量線を求めることがで きる。以下標準検量線および波長の重なり量の 求め方とてれを適用した例を示す。

\section{2 標隼検量線および波長の重なり量の求} め方

（a）波長の重なりのないとき

(2) 式より

$\mathrm{i}(\mathrm{x})=\frac{\mathrm{Wi}}{1+\sum \mathrm{aijW}_{\mathrm{j}}}$

（3）式で Wi，aijおよび Wj は既知なの で $\mathrm{i}(\mathrm{x})$ が計算できこれを $\mathrm{i}(\mathrm{x})$ cal とする。

組成のわかっている試料について $\mathrm{i}(\mathrm{x}) \mathrm{cal}$ を 計算し，与えられた分析条件で測定された䖢光 X線強度と $\mathrm{i}(\mathrm{x}) \mathrm{cal}$ をプロットし, とれらの点 をできるだけ滑らかに結べば i 元素の標準検量 線が得られる。こてで䖝光X線強度は絶対強度 でも強度比でも差支えない。

（b）波長の重なりがあるとき

波長の重なりがあるときの補正式は（4)式で 南わされる。
$\frac{W i+D i}{i(x)}=1+\sum a_{i j W}$

$\mathrm{Di}$; 純 $\mathrm{Fe}$-k系 2 元試料を用いて測定した $\mathrm{i}$ 元素のパックグランドの変動量を $\mathbf{i}$ 元素の標準検量線読取值で表わしたも の。一般に Wk の関数としてあらわさ れる。

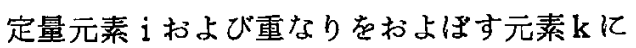
ついてi $(x)$ cal および $\mathrm{k}^{\prime}(\mathrm{x}) \mathrm{cal}$ を次のでとく定 める。

$$
\begin{aligned}
& \mathrm{i}(\mathrm{x}) \mathrm{cal}=\frac{\mathrm{Wi}}{1+\sum \mathrm{aijWj}_{\mathbf{j}}} \cdots \cdots \cdots \cdots \cdots \cdots(5) \\
& \mathbf{k}^{\prime}(\mathrm{x})_{\mathrm{cal}}=\frac{\mathrm{Wk}_{\mathrm{k}}}{1+\sum \mathrm{aijW}_{\mathrm{j}}}
\end{aligned}
$$

いま $\mathrm{i}$ 元素の蛍光 $X$ 線強度を $\mathrm{Ii}$ と, $\mathrm{i}(\mathrm{x}) \mathrm{cal}$ およびk' $(\mathbf{x}) \mathrm{cal}$ との間に(7)式を仮定し, 各試料 の值より係数 $\mathrm{b}_{1}, \mathrm{~b}_{2}$ および $\mathrm{b}_{3}$ を求める。すし 検量線が曲線になることが予想されるときは $\mathrm{i}(\mathrm{x}) \mathrm{cal}$ について高次の式を仮定すればよい。

$\mathrm{li}_{\mathrm{i}}=\mathrm{b}_{1 \mathrm{i}}(\mathrm{x}) \mathrm{cal}+\mathrm{b}_{2} \mathrm{k}^{\prime}(\mathrm{x}) \mathrm{cal}+\mathrm{b}_{3}$

これより Ii 対 $\left\{i(x) c_{c a l}+\left(b_{2} / b_{1}\right) k^{\prime}(x) c a l\right\}$ をプロットして $\mathrm{i}$ 元素の標準検量線が得られ， また $\left\{\left(\mathrm{b}_{2} / \mathrm{b}_{1}\right) \mathrm{k}^{\prime}(\mathrm{x})_{\mathrm{cal}}\right\}$ 対k' $(\mathrm{x}) \mathrm{cal}_{\text {を }}$ な゚ロット してDi が定まる。

\section{3 適用例}

5.2 (a)および 5.2 (b) の方法がどの程度有 効か確めるために 㸮光研究心誌上に発表され た測定データ ${ }^{15)}$ に適用してみた。とのデータは ノレルコ 100KV 定電压蛍光 $\mathrm{X}$ 線分析装置を使 用してステレンス鋼試料を测定したもので, 蛍 
光 $\mathrm{X}$ 線強度は標準試料の絈光 $\mathrm{X}$ 線強度にたいす る強度比の形で求められている。

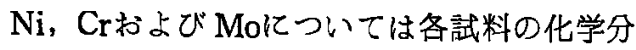
析値より $\mathrm{Ni}(\mathrm{x}) \mathrm{cal}, \mathrm{Cr}(\mathrm{x})_{\mathrm{cal}}$ わよびMo(x)cal を計算し, 蛍光 X線强度との関係を方眼紙上に
プロットして各元素の標準検量線を作製し，改 めて検量線より $\mathrm{i}(\mathrm{x})$ を求め，第 2 報の補正式の 数值を用いてX線分析値を計算し化学分析值と 比較すると第10表のでとくなった。また $\mathrm{Cr} の$ 標準検量線を第 6 図汇示す。

第 10 表 “分光研究” 誌のデータの補正結果

\begin{tabular}{|c|c|c|c|c|c|c|c|c|}
\hline \multirow{2}{*}{ 試 } & \multicolumn{2}{|c|}{$\mathbf{M n}$} & \multicolumn{2}{|c|}{$\mathrm{Ni}$} & \multicolumn{2}{|c|}{$\mathrm{Cr}$} & \multicolumn{2}{|c|}{ Mo } \\
\hline & $\begin{array}{c}\overline{\mathrm{X}} \text { 線分析值 } \\
(\%)\end{array}$ & $\begin{array}{c}\text { 化学分析值 } \\
(\%)\end{array}$ & $\begin{array}{c}\mathrm{X} \text { 線分析值 } \\
(\%)\end{array}$ & $\begin{array}{c}\text { 化学牙析值 } \\
(\%) !)\end{array}$ & $\begin{array}{c}\mathbf{X} \text { 線分析值 } \\
\end{array}$ & \begin{tabular}{|c|} 
化学分析值 \\
$(\%)$
\end{tabular} & $\begin{array}{c}\mathrm{X} \text { 線分析值 } \\
(\%)\end{array}$ & $\begin{array}{c}\text { 化学分析值 } \\
(\%)\end{array}$ \\
\hline 1 & 1.49 & 1.52 & 11.09 & 11.00 & 18. 36 & 18.48 & 0.22 & 0.23 \\
\hline 4 & 1.52 & 1.53 & 8.56 & 8.48 & 18.84 & 18.87 & 0.72 & 0.74 \\
\hline 6 & 0.28 & 0.31 & 9.12 & 9.11 & 17.94 & 17.93 & 0.04 & 0.04 \\
\hline 52 & 0.40 & 0.38 & 9.29 & 9.29 & 12.87 & 12.76 & 0.12 & 0.11 \\
\hline 54 & 0.25 & 025 & 8.65 & 8.68 & 15.87 & 15.86 & 0.10 & 0.10 \\
\hline 11 & 1.79 & 1.79 & 10.45 & 10.47 & 17.87 & 17.80 & 2.16 & 2.16 \\
\hline 15 & 1.67 & 1.67 & 14.97 & 15.01 & 17.33 & 17.44 & 2.50 & 2.52 \\
\hline 67 & 0.31 & 0.34 & 12.09 & 12.21 & 10.18 & 10.18 & 2.50 & 2.48 \\
\hline 70 & 1.08 & 1.08 & 13.36 & 13.41 & 14.12 & 14.26 & 2.24 & 2.22 \\
\hline 1185 & 1.25 & 1.22 & 13. 24 & 13. 18 & 17.21 & 17.09 & 2.02 & 2.01 \\
\hline 14 & 1.52 & 1.53 & 12.47 & 12.46 & 17.30 & 17.42 & 2.11 & 2.11 \\
\hline
\end{tabular}

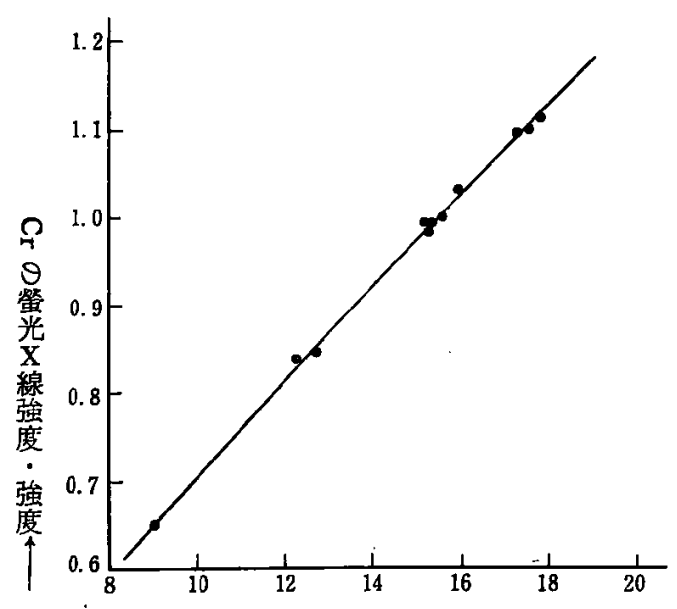

標準検量線読取值 $\mathrm{Cr}(\mathrm{X}) \%$

第 6 図 : 分光研究ミ誌データによる $\operatorname{Cr}$ の標準唡量線

MnについてはCrの波長の重なりが予想され るので $\mathrm{Mn}(\mathrm{x}) \mathrm{cal}$ およびCr' $(\mathrm{x})$ calを計算し，(7) 式の係数を求めて(8)式を得た。

$\mathrm{IMn}=0.494 \mathrm{Mn}(\mathrm{x}) \mathrm{cal}+0.0133 \mathrm{Cr}^{\prime}(\mathrm{x}) \mathrm{cal}$ $+0.061$

(8)式より $\mathrm{Mn} の$ 標準検量線は
$\mathrm{IMn}=0.494 \mathrm{Mn}(\mathrm{x})+0.061$

また DMn は

$\mathrm{DMn}=\frac{0.0133}{0.494} \mathrm{Wcr}$ (10)

と定まる。

(9）(10)式を用いて各試料のIMnおよびW crよ り $\mathrm{Mn}(\mathrm{x})$ および DMn を求め，第 3 報の補正式 を用いて MnのX線分析値を計算し，化学分析 值と比較すると第10表のごとくなった。第10表 の結果よりとの補正法が充分な正確度で適用さ れたととが認められる。

\section{6. 結}

諞

補正式の諸常数が分析条件によってどの程度 影響さ礼るかを検討し，次のごとき結果を得 た。: :

(1) X線管球ターゲット・管球電圧・管球電 流・装置によって補正式の諸常数は変化する。

(2) : 湘定元素の最低励起電圧上り充分高い電 圧を管球に加えれぱ，合金鋼の製品・炉中試料 の分析にて同じ補正式を用いたときの誤差は装 置の再現性および補正の誴差と同程度以下とな る。

(98頁へ続く) 
化するため割れを発生しやすい。ととろがマフ ラー用合金はC 含有量が低いため溶接後空冷し ても，マルテンサイトを生ぜず，辆れの心配は ない。このため,ての合金では椣々の溶接が可 能である。例えば，電気抵抗溶接（スポット， ミーム，プロジエクション溶接），高周波抵抗 溶接, TIG 溶接, 口ウ付け,など。

\section{2. 中抗張カマルェージング鋼}

最近進展した低コスト鋼AM-363について紹 介しているものであり，ての鋼はニッケルマル エーシング鋼と同様に㮱鈍状熋でマルテンサイ 卜構造となる。この合金は合金元素も低く強䩓 なマルテンサイトは得られるが，900 Fのエー シングでは強度がさほど増すわけではない。と の鋼の組成は, $0.05 \mathrm{Cmax}, 0.30 \mathrm{Mnmax} 0.15$ Simax, $11.5 \mathrm{Cr}, 4.5 \mathrm{Ni}, 0.40 \mathrm{Ti}$ であり, 焼鈍 状態で降伏強サ, 100, $000 \mathrm{psi}$ ，引張強サ 120,000 $\mathrm{psi}$ ，伸ビ $8 \% ， \mathrm{H}_{\mathrm{R}} \mathrm{C} 23 \sim 28$ を保証している。

ての鋼は特に大気中食住対して良好な耐食 性を示す。組成としてCが低く，Ti，Ni 点 有するので，目でみえるようなサビ，酸化皮膜 は決して生じない。この鋼には耐食性の外に すぐれた溶接性を有するという特長を持ってい る。予熱, 後熱なしに溶接を行っても溶接のま まの溶接金属に母材同等の強性, 鞄サ, 延性を 持たせることができる。

\section{(74頁より続く)}

(3) 補正式が実用的には変動しないとする立 場より，標準検量線を用いる補正式を鉄系 2 元 合金試料がないときに適用する方法を述べ，こ れを実際に適用して良好な緢果を得た。

本研究の遂行にさいし装置の使用について御 便宜をはかっていただいた島津製作所科学器械 工場遠山健次郎課長, 同築山公係長に厚く感謝 します。

$$
\text { 〔参考文 献〕 }
$$

1) 杉本正勝：分光研究， 12 (1964) p 161

2) G. Anderman, J.W. Kemp : Anal. Chem. , 30. (1958) p 1306

3) P.K.Koh, B. Caugherty : J.Appl. Phys., 23 (1952) p 427
TIG，MIG 溶接することができ，その他， 霓気抵抗溶接など多くの溶接法が利用できる。 この鋼は航空機や列車の外殼, 舶用容器, トレ 一ラトラックボデイなどに使用される。

\section{3. 高カステンレス龬}

$\mathrm{AM}-350(0.08 \mathrm{C}, 16.5 \mathrm{Cr}, 4.25 \mathrm{Ni}, 2.75 \mathrm{Mo}$ $0.10 \mathrm{~N})$ について報告しているものであり，乙 の合金は焼銛状態でオーステナイト組織とな る。完全硬化せしめるには $-100^{\circ} \mathrm{F} \times 3 \mathrm{hr}$ 深冷 処理， $850^{\circ} \mathrm{F} \times 3 \mathrm{H}$ 焼戻しが必要であり，ての ように処理すると次のごとき性質が得られる。

\begin{tabular}{|c|c|c|c|c|}
\hline $1900^{\circ} \mathrm{F}$ で焼鈍 & $\begin{array}{c}\mathrm{HRC}_{2} \mathrm{C} \\
20\end{array}$ & $\begin{array}{l}\text { YS } \\
\text { ps } \\
60,000\end{array}$ & $\begin{array}{c}\text { TS } \\
\text { psi } \\
145,000\end{array}$ & 伸ヒ́ \\
\hline \multirow{2}{*}{$\begin{array}{l}\mathrm{SCT}\left(850^{\circ} \mathrm{F}\right) \\
\text { 溶接継手 SCT } \\
\left(850^{\circ} \mathrm{F}\right)\end{array}$} & 45 & 173,000 & 206,000 & 15 \\
\hline & 45 & 173,000 & 203,000 & 16 \\
\hline S.C.T. & & & & \\
\hline
\end{tabular}

この鋼は大なる強度と耐食性の要求される溶 接構造物に適し，ての鋼を溶接するに当っては 予熱, 後熱は必要ないが，母材と同等の強度を 得るには深冷処理および $850^{\circ} \mathrm{F}$ 焼戻しをする必 要がある。ステンレス䤡に適用できる溶接法は いずれもこの鋼にも適用できる。この合金とよ く似た合金にAM-355があり，るちろん管材， 板材，鉔造品，鋳造品としても使われるが，口 イヤにして，溶接用充媜金属として使いうると 著者はのべている。

(竹 内)

4) H. J.Beattie, R.M. Brissey : Anal, Chem, . 26 (1954) p 980

5）杉本正勝：分化.，吕（1962） p 1168

6）足立敏夫，伊藤六仁：電気製鋼， 34 (1963) p384

7）桃木弘三：工化.， 64（1961）p 98

8）広川吉之助：日本金属会誌，24（1960）p 692

9）杉本正勝：分化，，年（1963） p 475

10) W. Marti : Spectrochi. Acta, 17 (196்1) p379

11）一柳炤成，沢田敏男：分化， 13 (1964) p 860

12）足立敏夫，伊藤六仁：電気製鋼， 34 (1963) p 5

13）日本铁鋼協会共同研究会鉄鋀分析部会賀料 F X62（昭和39年11月）

14）足立敏夫，伊藤六仁：電気製鋼， 35（1964）p178

15）杉本正腾：分光研究， 吕（1963） p 262 